IZA DP No. 8892

Compulsory Military Service and Future Earnings: Evidence from a Quasi-Experiment

Muhammad Asali

February 2015 


\title{
Compulsory Military Service and Future Earnings: Evidence from a Quasi-Experiment
}

\author{
Muhammad Asali \\ Tbilisi State University \\ and IZA
}

\section{Discussion Paper No. 8892 \\ February 2015}

\author{
IZA \\ P.O. Box 7240 \\ 53072 Bonn \\ Germany \\ Phone: +49-228-3894-0 \\ Fax: +49-228-3894-180 \\ E-mail: iza@iza.org
}

\begin{abstract}
Any opinions expressed here are those of the author(s) and not those of IZA. Research published in this series may include views on policy, but the institute itself takes no institutional policy positions. The IZA research network is committed to the IZA Guiding Principles of Research Integrity.

The Institute for the Study of Labor (IZA) in Bonn is a local and virtual international research center and a place of communication between science, politics and business. IZA is an independent nonprofit organization supported by Deutsche Post Foundation. The center is associated with the University of Bonn and offers a stimulating research environment through its international network, workshops and conferences, data service, project support, research visits and doctoral program. IZA engages in (i) original and internationally competitive research in all fields of labor economics, (ii) development of policy concepts, and (iii) dissemination of research results and concepts to the interested public.
\end{abstract}

IZA Discussion Papers often represent preliminary work and are circulated to encourage discussion. Citation of such a paper should account for its provisional character. A revised version may be available directly from the author. 
IZA Discussion Paper No. 8892

February 2015

\section{ABSTRACT \\ Compulsory Military Service and Future Earnings: Evidence from a Quasi-Experiment ${ }^{*}$}

Using Israeli census data, this study provides new evidence on the long-term effects of military service on the earnings of veterans. Among Druze men aged 25-34, we find an economically and statistically significant positive effect of $18 \%$ on their wages. The respective effect for the 35-44 age group is $23 \%$. The positive effects are large and intensify with time. Skill-enhancement and usual human capital accumulation do not explain the positive effect of military service. Networking and widening the circle of contacts during service are suggested as the most likely explanations.

JEL Classification: J24, J31, J45

Keywords: military service, future earnings, social capital

Corresponding author:

Muhammad Asali

International School of Economics

Tbilisi State University

16 Zandukeli Street

Tbilisi 0108

Georgia

E-mail: muhammad.asali@gmail.com

\footnotetext{
* I am indebted to Randy Filer, Janet Currie, and Ira Gang for their generous comments. Thanks also go to seminar participants of the European Association of Labor Economists, and ISET, for their comments. All remaining errors are mine.
} 
"The son of a creditable labourer or artificer may frequently go to sea with his father's consent; but if he enlists as a soldier, it is always without it." Adam Smith. The Wealth of Nations.

\section{Introduction}

Are veterans adequately compensated for their service? Neither the relevance nor the importance of this question has abated since it was first posed. The very nature of coercion in recruitment renders soldiers incurring economic losses, due to the embedded hidden tax imposed by mandatory service (Oi 1967), or to losing valuable civilian labor market experience (Angrist 1990). It was on these grounds that John Maynard Keynes opposed conscription claiming that he was "not prepared on such an issue to surrender [his] right of decision" (Johnson 1960).

On the other hand, military service can potentially enhance the human capital of conscripts. It also provides a "buffer against adverse labor market conditions" (Hisnanick 2003). While some researchers argue to the contrary, it is still possible that skills gained in the army are useful for civilian careers. Such benefits are more likely to accrue to disadvantaged groups, whose backgrounds most likely miss the qualities provided in the military: Elder (1986) lists qualities like firm discipline, teamwork and cooperative relations, social responsibility, leadership, and competent role models. Furthermore, there is the usual help provided by many governments after the service: cash grants as well as in kind support, like the benefits provided to veterans in the G.I. Bill in the USA, or similar end-of-service benefits in Israel.

Whether military service has an effect on future outcomes (employment, wages, education, and health), therefore, is an empirical question. Studies on the issue are numerous, and are not unanimous as to the actual estimated effect, especially due to selectivity concerns embedded in the very nature of an all-volunteer force. This and the absence of counterfactuals impose difficulties in disentangling the causal effect from the mere correlation. Researchers have used different econometric 
methods to provide reliable estimates of this effect (e.g., natural experiments and draft lotteries as in Angrist (1990, 2011); birthdate as in Angrist and Krueger 1994; change in regulations as in Bauer et al. 2012, among others).

Berger and Hirsch (1983) reported a positive return for black workers (or disadvantaged youth in general, whose civilian job opportunities are scarce), and zero effect for white veterans. Hirsch and Mehay (2003) reported negative but small effects for white enlisted personnel and a positive 5\% effect among African Americans.

In his seminal work, Angrist (1990) found a negative 15\% effect on the earnings of white veterans (but an insignificant effect on the earnings of black veterans). A similar pattern was reported in Angrist (1998). Angrist and Chen (2011) found that the negative effects experienced by veterans in the 1990s faded by the end of the 1990s, a finding that is echoed in Angrist, Chen, and Song (2011), who deem this outcome consistent with the loss-of-experience interpretation of the negative effect of service.

Grenet, Hart, and Roberts (2011) found no effect of military conscription on long-term real earnings in Britain; they postulate that the skills acquired during military service are just enough to compensate for the lost civil market experience, resulting in a zero net effect of the service. Bauer et al. (2012), analyzing the effect in Germany, found that the $17 \%$ earnings advantage of veterans vanished once they corrected for selection biases. Card and Cardoso (2012), analyzing the effect for Portugal, found a significant 4-5\% impact of service on the wages of unskilled men (with primary education only), but zero effect on the wages of men with more than primary education.

Despite the fact that many countries changed their recruitment procedures for military personnel and are now relying on all-volunteer forces (e.g., the United States, the United Kingdom, France, Italy, Spain, Portugal, and other Eastern European countries), compulsory military service is 
still the norm in many countries (e.g., Austria, Denmark, Switzerland, and Greece), Bauer et al. (2012). Military service is still mandatory also in Israel. In this paper we utilize peculiarities in the Israeli law to obtain unbiased estimates of the effect of mandatory military service on subsequent (medium and long-term) earnings in the labor market.

The identification strategy in this study is based on the fact that the Israeli law and practice make military service mandatory for some groups of the population (Israeli Jews and Israeli Druze Arabs), and exempt other groups of the population from service (Israeli non-Druze Arabs-Muslims and Christians). The focus is on the serving Druze Arabs versus the non-serving non-Druze Arabs.

We find that the earnings benefits associated with military service are substantial and significant: about $18.5 \%$ for the whole group of male Druze workers, and $18 \%$ for the unskilled workers of this group (with zero to twelve years of schooling). Fifteen to twenty-five years after the completion of their service, the returns amount to $23.7 \%$ and $22.5 \%$, respectively. The usual human capital channels (like experience, schooling, and internal migration) fail to explain the large premium of military service. Elements of social capital, most importantly networking, stand out as a likely explanation for this premium. Obviously, that is in addition to the fact that, due to Israel's particular history and sociopolitical situation, the military plays an important role in the Israeli society, explaining the large military premium found in this study. ${ }^{1}$

The next section provides a brief background on the Druze and the institutional setting of the conscription process in Israel. Section III describes the data used in this study. The empirical strategy is outlined in section IV. Section V presents the main findings of this study, and section VI provides concluding remarks.

\footnotetext{
${ }^{1}$ See a brief history of the army and its standing in the Israeli society in this article from the Jewish Agency for Israel: $<$ http://jafi.org/JewishAgency/English/Jewish+Education/Compelling+Content/Eye+on+Israel/Society/9)The+Role+of + the+Military+in+Israel.htm>, accessed 01-02-2015.
} 


\section{Background: Military Service in Israel and the Druze}

\section{A. The Druze in Israel}

The Arab minority in Israel is composed of three groups: Muslims, Christians, and Druze. The Druze constitute about 8 percent of the entire minority population. Under the Islamic Fatimid dynasty, the Druze was declared as a new religion in Egypt in 1017. Some of the following Fatimid caliphs suppressed and persecuted the Druze rendering them fleeing to Lebanon, Syria, and the Galilee region of north Palestine. The Druze are populating these areas to this day (Atashi 1997).

Allegedly, the Druze originally sought protection and livelihood by enlisting in the Haganah (a Jewish underground organization established in 1920; later, after the inception of the state, this became the Israel Defense Forces, IDF), as they were paid for their service until 1956.

The fact that "the Druze have customarily maintained allegiance to the incumbent regime in the regions where they have lived, as long as that regime has respected their way of life and their religion" (p.166, Atashi 1997) is frequently listed as the main reason behind the Druze service in the Israeli army.

The state granted the Druze community the status of independent religion in 1957 , later in 1961 it recognized their Sheikh Amin Tarif as a "spiritual authority." Despite all the seemingly assimilation steps taken by the state, the Druze, who are Arab by origin, culture, nationality, and language were treated as such by the state, namely lacking the preferential treatment enjoyed by Jewish citizens: "[Druze university graduates] failed to find a productive place in Israeli society owing to a lack of suitable jobs into which they could be absorbed, except in the ministry of education [as teachers]...The other government ministries admitted no Druze" (p.116, Atashi 1997). The Druze, moreover, do not deny their being Arabs, although the state officially treats them as a different group. This is also confirmed in studies based on interviews with the Druze youth (Nisan 2010). 
For obvious geopolitical reasons, it is argued that the special symbolic and non-symbolic treatments of the Druze by the state (like changing their nationality in the ID cards from "Arab" to "Druze" in the former, and enforcing military service law in the latter) were motivated only by the state's desire to alienate and separate the Druze from their fellow Arabs (Atashi 1997; Cohen 2009; Cohen 2010).

\section{B. Military Service in Israel}

Military service in Israel has been mandatory since its inception. Article 1 of the Defense Service Law of 1949, and in its updated version of 1986 (Knesset 1949, Knesset 1986; henceforth "the law") mandates that every Israeli citizen or permanent resident, who turns 18 , must be enlisted, regardless of his or her race, religion, nationality, or ethnicity.

The length of military service has changed over the years. According to the Defense Service Law of 1949, Articles 6(b)1 and 6(c), males have to serve for two years and females for one year. Nowadays, and based on Articles 15 and 16 of the updated version of the law, males have to serve for three years (within the 18-21 age interval) and females for two years.

Various segments of the Israeli population were exempt from military service: some directly by the rulings of the law, and others by "arrangements" between state officials (like the defense minister) and different communities. For example, a mother, a pregnant woman, a married woman, or a woman declaring religious commitment that ban her from service are all exempt from service by Article 11 of the Defense Service law in its original 1949 format (Articles 39 and 40 of the 1986 law).

On the other hand, Ultra-Orthodox Jews - those whose main occupation is to study (Torah) in the Yeshiva, aka "Torato Omnoto"-were exempt from service at the discretion of the defense minister (a privilege given to him by Article 36 of the Defense Service law), until this was challenged by a ruling of the Supreme Court in 1997, which declared unlawful the defense minister's decisions 
to grant service deferrals to Ultra-Orthodox youth. The Supreme Court decided that it is the legislation authority's (the Knesset's) call to instate a new law that settles this matter. ${ }^{2}$ The Knesset indeed enacted a new law (known as Tal's Law, named so after the honorable judge Tzvi Tal) in 2002, which essentially maintained the status quo as to the arrangement with Ultra-Orthodox Jews. ${ }^{3}$ After two 5year extensions of this law, in 2012, the Supreme Court decided that Tal's law was unconstitutional and would not be extended after its expiry date of 1-Aug-2012. ${ }^{4}$

Israeli Arabs, unlike the aforementioned cases of women or Ultra-Orthodox Jews, have never been granted an official exemption from service. ${ }^{5}$ The mandatory service duty, nonetheless, was never enforced on most of the Israeli (Muslim and Christian) Arab communities living in Israel, resulting in them practically not serving in the army $(\operatorname{Orgad} 2007){ }^{6}$

In the absence of de jure exemption for these Arab communities, their de facto non-service was made possible by an inaction on the state part. Article 13 of the law states that an enumerator, appointed by the defense minister, is entitled to call people who turn 18 to service. The enumerator has simply never called Israeli Arabs to service, practically (and passively) granting them an exemption. Retroactively, the enumerator's decision not to call Arabs for service was in line with military command no. 01-01, given in 1986 by the chair of the human resources division, which states that: "... as a rule, this population [Arab Muslims, and Arab Christians] shall not be enlisted..." (Orgad 2007).

\footnotetext{
${ }^{2}$ See section 43 of the Supreme Court's judgment number $3267 / 97$ (found on http://elyon1.court.gov.il/files/97/670/032/A11/97032670.a11.htm, last accessed 14-Jan-2014).

${ }^{3}$ Tal's law is found here http://www.knesset.gov.il/laws/heb/FileD.asp?Type=1\&LawNum=1862\&SubNum=9, accessed 16-Jan-2014).

${ }^{4}$ See http://www.haaretz.co.il/news/education/1.1646921 (accessed 16-Jan-2014).

${ }^{5}$ The Israeli population is composed of $80 \%$ Jews and $20 \%$ non-Jews, of which $17 \%$ are non-Druze Arabs (Muslims and Christians) and $1.7 \%$ are Druze Arabs.

${ }^{6}$ Very few Muslims and Christians volunteer to serve in the army, nevertheless. The Israeli Defense Forces (IDF) does not release data about enlisted soldiers, let alone their decomposition by religion; however, as it appears from reports in the public media, the number of Muslim (and Christian) Arab volunteers does not exceed a few dozens (see Orgad 2007, p.383 n.11).
} 
Unlike other Israeli Arabs, the Druze in Israel have to serve in the army, and the Defense Service law is strictly enforced in their case. In 1955, allegedly "due to frequent requests of Druze leaders for the law to be enforced on them similar to their Jewish counterparts"- as claimed by the government - and due to a massive support of military leaders for Druze to join the army, it was decided that the Defense Service law should be enforced on the Druze (male) community starting January $1956\left(\right.$ Orgad 2007). ${ }^{7}$

The evidence of many Druze leaders, dignitaries, scholars, and organizations opposing the mandatory military service, however, shows clearly that the service was imposed on this community by force rather than choice. "In opposition to the common wisdom and in partial contradiction to Israel's claim that the Druze asked to be conscripted, they were, to put it mildly, lukewarm about serving in the IDF. Even among the community's leadership, only a handful—led by some members of Knesset-voiced enthusiastic support for army service” (p.160, Cohen 2010). The security authorities, believing that the Druze leaders were not doing their "job" of convincing the Druze youth to serve in the army and to prepare the ground for army service among them, decided to "take matters into their own hands and to break the Druze resistance to enlistment. They used incentives..., as well as force" (ibid).

Similar evidence is brought by Cohen (2009): “Among the Druze, there was already some organized resistance to Israeli rule in the 1950s, which took the form of opposition to the 1956 national military service law." In the early 1970s a major part of the Druze community established the Druze Enterprise Committee whose major message was: “...the Druze are an integral part of the Palestinian

\footnotetext{
${ }^{7}$ The Defense Service Law is also enforced on the Circassians (starting 1958), who are non-Arab Muslims-but this is a very tiny segment of the Israeli population (there were only about 4000 Circassians living in Israel in 2007, see, for example, http://www.ynet.co.il/articles/0,7340,L-3413724,00.html; accessed 13.01.2014). In our data Circassians cannot be identified because they are reported as "Muslims" and thus cannot be distinguished from Arab Muslims. Knowing that this community is concentrated in two villages only: Kafar-Kama and Reihaneya, however, one can identify Circassians by the code of their localities. It appears that there are only 46 observations of Circassians with positive income in the data: dropping these observations has virtually no effect on the results in this study.
} 
Arab population in Israel and the same laws should apply to them as to the rest of Arab society regarding military service." This committee joining others, and gaining momentum under different names, continued lobbying against the conscription of the Druze into the IDF. Practically, however, nothing changed in that the voiced statement remained that "the general consensus among the Druze leadership is that Israel's Druze population must continue to play its part on behalf of Israel's security" (p.71, Cohen 2009). This evidence shows that the government treated the Druze as a different group from their fellow Arabs in order to "distance the Druze community from the Arab population by fostering a special, separate Druze identity.” (p.104, Atashi 1997).

To sum up, the Druze are part of the Arab minority in Israel. Except for mandatory military service and different "nationality affiliation" in their ID cards, they are otherwise Arab citizens of Israel like any other group of the Arab minority, having similar schools and local labor markets, following similar educational curriculum, and sharing the same mother tongue (Arabic; besides, the Druze, given the historic origins of this group, celebrate the same religious holidays with the Muslims). On the other hand, their service in the army is not a choice or an evidence for self-selection: instead, they have to serve in the army by decree of law (which was accepted due to foreign considerations, like self-interest of some leaders of the community, or the desire of the state to separate the Druze from their Arab brethren). These two facts render the comparison between non-Druze Arabs and Druze Arabs an ideal "controlled experiment," and, as such, proving the genuine causality of the measured effect of military service on future earnings.

\section{Data and Background}

The analysis in this study relies on data from the 1995 population census of Israel, carried out by the Central Bureau of Statistics (CBS) of Israel. The 1995-census is the last publicly available census; besides, is an ideal timing for studying peacetime effect of military service — as 1995 was 
relatively a peaceful year in Israel: 8 years after the first intifada, 5 years before the second intifada, and right after the Oslo peace accords between the Israelis and the Palestinians.

The census is the most comprehensive source of demographic, social, and economic data about the Israeli population. It covers $20 \%$ of the Israeli population — of all ages. The analysis in this study pertains to individuals who filled out the extended questionnaire, whose age is 15 years or older. ${ }^{8}$

Due to privacy considerations and requirements of statistical confidentiality-so that individuals cannot be identified through their detailed demographic variables - the CBS prepared two versions of the census file: the demographic version and the geographic version. I use the geographic version in this study. ${ }^{9}$ Each of these versions details a few variables but extensively groups others. The schooling, weekly working hours, and income variables were grouped as such in the original data - and, in constructing some of the figures to follow, were converted to continuous variables by choosing the midpoint of each interval. ${ }^{10}$

Table 1 presents the summary statistics of the main variables in this study. The table pertains to male workers with nonzero income, and non-missing weekly working hours data. Column 1 reports the means and standard deviations for the variables from the pooled sample: all Arab and Jewish workers, aged 44 or below. Columns 2 and 5 refer to Jewish workers aged 25-34 and 35-44, respectively. Columns 3 and 6 refer to Druze (Arab) workers aged 25-34 and 35-44, respectively; and

\footnotetext{
${ }^{8}$ It is worth noting that the income surveys, also maintained by the CBS, potentially provide a more detailed source of information, as they cover more demographic aspects of the respondents, besides providing exact values of the variables rather than intervals. They are also available on a yearly basis, unlike the census which is available only once in a decade. However, the income surveys could not be used for analyses because they miss the most important variable for identification in this study, which is the religion of the respondent. The income survey reports whether the individual is an Arab or Jewish, but does not specify the Arab's religion: Druze, Muslim, or Christian.

${ }^{9}$ This is the "Census Stage B" file. The 1995 census covers the population as of November 4, 1995. It includes transitory residents and foreign workers, but these are excluded in the analyses in this study. Institutionalized individuals are not included in the census. The original sample includes 1,113,420 observations.

${ }^{10}$ Alternatively, an imputation based on a uniformly distributed variable over the given interval was used and produced similar results.
} 
columns 4 and 7 refer to non-Druze Arab workers (i.e., Christian and Muslim Arab workers) aged 2534 and 35-44, respectively.

TABLE 1 -SUMMARY STATISTICS

\begin{tabular}{|c|c|c|c|c|c|c|c|c|c|}
\hline & \multirow[b]{2}{*}{$\begin{array}{l}\text { All } \\
\text { (1) }\end{array}$} & \multicolumn{3}{|c|}{ Age $25-34$} & \multicolumn{5}{|c|}{ Age $35-44$} \\
\hline & & $\begin{array}{l}\text { Jews } \\
(2)\end{array}$ & $\begin{array}{l}\text { Druze } \\
(3)\end{array}$ & $\begin{array}{l}\text { Non-Druze } \\
\text { Arabs } \\
\text { (4) }\end{array}$ & Diff. & $\begin{array}{l}\text { Jews } \\
(5)\end{array}$ & $\begin{array}{l}\text { Druze } \\
(6)\end{array}$ & $\begin{array}{l}\text { Non-Druze } \\
\text { Arabs } \\
\text { (7) }\end{array}$ & Diff. \\
\hline Monthly earnings (NIS) & $\begin{array}{l}4799.2 \\
(3934.2)\end{array}$ & $\begin{array}{l}4983.4 \\
(3339.0)\end{array}$ & $\begin{array}{l}3965.9 \\
(2109.4)\end{array}$ & $\begin{array}{l}3158.2 \\
(1872.9)\end{array}$ & $\begin{array}{l}807.7 * * * \\
(72.1)\end{array}$ & $\begin{array}{l}7128.8 \\
(4975.2)\end{array}$ & $\begin{array}{l}4918.7 \\
(3204.0)\end{array}$ & $\begin{array}{l}3941.4 \\
(2892.8)\end{array}$ & $\begin{array}{l}977.3 * * * \\
(132.9)\end{array}$ \\
\hline Schooling Years: 0-12 (\%) & $\begin{array}{l}67.5 \\
(46.8)\end{array}$ & $\begin{array}{l}57.6 \\
(49.4)\end{array}$ & $\begin{array}{l}81.2 \\
(39.1)\end{array}$ & $\begin{array}{l}80.6 \\
(39.5)\end{array}$ & $\begin{array}{l}0.6 \\
(1.51)\end{array}$ & $\begin{array}{l}58.9 \\
(49.2)\end{array}$ & $\begin{array}{l}77.4 \\
(41.9)\end{array}$ & $\begin{array}{l}75.5 \\
(43.0)\end{array}$ & $\begin{array}{l}1.8 \\
(1.95)\end{array}$ \\
\hline Schooling Years: 13+ (\%) & $\begin{array}{l}32.5 \\
(46.8)\end{array}$ & $\begin{array}{l}42.4 \\
(49.4)\end{array}$ & $\begin{array}{l}18.8 \\
(39.1)\end{array}$ & $\begin{array}{l}19.4 \\
(39.5)\end{array}$ & $\begin{array}{l}-.6 \\
(1.51)\end{array}$ & $\begin{array}{l}41.1 \\
(49.2)\end{array}$ & $\begin{array}{l}22.6 \\
(41.9)\end{array}$ & $\begin{array}{l}24.5 \\
(43.0)\end{array}$ & $\begin{array}{l}-1.8 \\
(1.95)\end{array}$ \\
\hline Weekly Working Hours & $\begin{array}{l}41.7 \\
(10.6)\end{array}$ & $\begin{array}{l}42.4 \\
(9.8)\end{array}$ & $\begin{array}{l}43.0 \\
(9.2)\end{array}$ & $\begin{array}{l}41.9 \\
(10.3)\end{array}$ & $\begin{array}{l}1.1^{*} \\
(.39)\end{array}$ & $\begin{array}{l}44.0 \\
(7.6)\end{array}$ & $\begin{array}{l}41.0 \\
(10.9)\end{array}$ & $\begin{array}{l}41.8 \\
(9.3)\end{array}$ & $\begin{array}{l}-.8 \\
(.43)\end{array}$ \\
\hline Married (\%) & $\begin{array}{l}64.4 \\
(47.9)\end{array}$ & $\begin{array}{l}65.7 \\
(47.5)\end{array}$ & $\begin{array}{l}86.6 \\
(34.0)\end{array}$ & $\begin{array}{l}81.5 \\
(38.8)\end{array}$ & $\begin{array}{l}5.2 * * \\
(1.5)\end{array}$ & $\begin{array}{l}91.1 \\
(28.5)\end{array}$ & $\begin{array}{l}97.7 \\
(14.9)\end{array}$ & $\begin{array}{l}97.8 \\
(14.8)\end{array}$ & $\begin{array}{l}-.05 \\
(.7)\end{array}$ \\
\hline Single $(\%)$ & $\begin{array}{l}33.8 \\
(47.3)\end{array}$ & $\begin{array}{l}32.7 \\
(46.9)\end{array}$ & $\begin{array}{l}13.2 \\
(33.9)\end{array}$ & $\begin{array}{l}18.0 \\
(38.4)\end{array}$ & $\begin{array}{l}-4.7 * \\
(1.5)\end{array}$ & $\begin{array}{l}5.2 \\
(22.2)\end{array}$ & $\begin{array}{l}1.7 \\
(13.0)\end{array}$ & $\begin{array}{l}1.5 \\
(12.1)\end{array}$ & $\begin{array}{l}.2 \\
(.6)\end{array}$ \\
\hline Observations & 98,355 & 28,728 & 741 & 9,638 & 10379 & 29,630 & 526 & 5,776 & 6302 \\
\hline
\end{tabular}

Notes: Standard deviations in parentheses. Monthly earnings, in 1995 New Israeli Shekels (NIS), are calculated from the midpoints of the reported income variable (in 1995 a $\$ 1$ was worth about 3 NIS). The category 'All' includes the pooled sample of individuals aged 44 or below. Samples include only males with positive earnings and non-missing weekly working hours. "Diff" is the difference in the means of the different variables between Druze and non-Druze Arabs within each category (with standard errors in parentheses). * significant at the $1 \%$ level, ** at the $0.1 \%$, *** at the $0.01 \%$.

Source: Author's calculations from the Israeli Census of 1995.

It is apparent from the table that, within each age group, Jewish workers have the highest earnings, remotely followed by their Arab counterparts: Druze and non-Druze. Druze males earn significantly higher salaries than their non-Druze counterparts. ${ }^{11}$ However, for the pretreatment samples, the wages of Druze and non-Druze Arabs are very close: 2553 and 2379, and 1932 and 2040 for the 15-24 and 15-19 age groups, respectively.

Druze males seem to marry a bit earlier than non-Druze Arabs, but for the older group of workers (35-44) the marital status of these two communities is near identical. Educational patters, and

\footnotetext{
${ }^{11}$ See Asali (2010) for an overview of the Jewish-Arab wage gap, its evolution, and causes in the 1990s and the early 2000s. Notice also that Palestinians are not covered in our data, and their effect on Israeli Arab workers (including Druze) is not covered in this study; for that see Asali (2013).
} 
working hours, for the Druze and non-Druze Arabs are also very similar for both age groups. These are not comparable to their Jewish counterparts.

\section{Empirical Strategy}

The identification strategy in this study is based on Israeli law and practice, which make military service mandatory for Druze Arabs, but exempt other Israeli Arabs from service. ${ }^{12}$ We are interested in measuring the average causal effect of military service as

$$
E\left(w_{1 i}-w_{0 i} \mid X_{i}\right)
$$

where $w_{1 i}$ is the potential wage of individual $i$ if he serves in the army, and $w_{0 i}$ is the potential wage of this individual if he does not serve in the army. $X_{i}$ is a set of control variables like education, age, and marital status. However, since we observe the individual only in one state of nature (either served or not), we can only compare the wages of those who serve with those who do not. Let $S$ stand for "serve in the army," so that it takes on the value 1 if the individual serves and zero otherwise, then we observe $E\left(w_{i} \mid S_{i}=1, X_{i}\right)-E\left(w_{i} \mid S_{i}=0, X_{i}\right)$ which is equal to

$$
E\left(w_{1 i}-w_{0 i} \mid S_{i}=1, X_{i}\right)+\left[E\left(w_{0 i} \mid S_{i}=1, X_{i}\right)-E\left(w_{0 i} \mid S_{i}=0, X_{i}\right)\right]
$$

The second term is the "selection bias" (see Angrist and Pischke 2008). In our context, where military service is mandatory for some people (Druze) who actually serve and not for others (nonDruze Arabs) who thus do not serve, the service variable, $S$, is not a choice variable. In other words, the conditional independence assumption holds by definition, meaning that the potential wage $\left(w_{0 i}\right.$ and $\left.w_{1 i}\right)$ is not correlated with the actual status, whether one serves in the army or not $\left(S_{i}=1\right.$ or $S_{i}=$

\footnotetext{
${ }^{12}$ It might be tempting to compare the wages of Israeli Jews with these of non-serving Israeli Arabs, however this comparison will not reveal the effect of military service because the differences are marred with other confounding variables like labor market discrimination and other wage determinants that are not comparable across these groups (Asali 2010).
} 
0). Therefore, the selection bias disappears, and the observed difference in wages between those who serve and those who do not boils down to $E\left(w_{1 i}-w_{0 i} \mid S_{i}=1, X_{i}\right)$ which is equal to the average causal effect in question, because $S$ is independent of $w_{i}$, conditional on observable controls (that is, $\left.\left\{w_{0 i}, w_{1 i}\right\} \perp S_{i} \mid X_{i}\right)$. Therefore,

$$
E\left(w_{i} \mid S_{i}=1, X_{i}\right)-E\left(w_{i} \mid S_{i}=0, X_{i}\right)=E\left(w_{1 i}-w_{0 i} \mid X_{i}\right)
$$

In essence, the institutional setting in Israel provides a natural experiment setting - in which people are assigned to or exempt from service regardless of their own choices or characteristics as in a randomized experiment - that can be utilized to address the question of the effect of military service on labor market outcomes.

Given that Druze males have to serve in the army while non-Druze Arab males are exempt, we can capture the effect of military service on wages by estimating the following equation (for males only):

$$
\text { (1) } \ln \left(\text { wage }_{i}\right)=\alpha+\boldsymbol{X}_{i} \beta+\gamma_{1} D R U Z E_{i}+\gamma_{2} S E R V E_{i}+\gamma_{3} S E R V E_{i} \times D R U Z E_{i}+\varepsilon_{i} \text {, }
$$

where wage $_{i}$ is the monthly wage of individual $i, D R U Z E_{i}$ is a dummy variable that takes on the value one if individual $i$ is a Druze worker and zero otherwise, $S E R V E_{i}$ is a dummy variable that takes on the value one if individual $i$ is 25 years old or older (i.e., after military service age, which is 18-21) and zero otherwise. ${ }^{13} \boldsymbol{X}_{\boldsymbol{i}}$ is a vector of control variables the controls for a wide range of demographic and work-related variables, in particular it includes dummies for educational attainment (0 years of schooling, 1-4, 5-8, 9-10, 11-12, 13+), marital status dummies (married, single, divorced, separated,

\footnotetext{
${ }^{13}$ The dummy variable for age being 21 (25) or older is almost a perfect substitute for the actual military service variable. That is because all Druze males have to serve in the army (except for the very few who are deemed Sheikhs or religious, who are probably not in our sample). In the population, ignoring the religious group, service among the Druze reaches $93 \%$, a near perfect compliance ratio - and much higher than among the Jewish population. This fact can be inferred from reports by military officials in the IDF: see, People Israel, the Samuel Neaman Institute for Advanced Studies in Science and Technology, http://www.peopleil.org/details.aspx?itemID=7673, accessed 26-1-2015; and the IDF web site: http://www.idf.il/1133-15851-HE/Dover.aspx, accessed 26-1-2015.
} 
widowed), age group dummies, district, sub-district, type of locality, locality of workplace, schooling status (currently studying, studied in the past, or never studied), number of marriages (never, once, more than once), weekly working hours, status at work, industry fixed effects (16 categories), and occupation fixed effects ( 9 categories). $\varepsilon_{i}$ is a white-noise error term.

The coefficient of interest is $\gamma_{3}$, measuring the difference-in-differences (DD) effect of military service on wages. The DD approach is used to control for other unobserved differences between Druze and non-Druze Arab males as they transition from the treatment or pretreatment era into after treatment. As a placebo analysis we also estimate the above equation for Druze and nonDruze Arab females, of whom none serves in the army. If our DD estimator is to capture the effect of military service on future earnings, the "effect" of the (nonexistent) military service for Druze females should thus not be different from zero.

Equation 1 is estimated by the method of interval regression, based on a maximum-likelihood procedure, because the dependent variable is reported in intervals rather than in levels. This method was introduced by Stewart (1983); when feasible, in the case of interval dependent variable, this method produces estimators that possess more desirable statistical properties that their ordinary least squares counterparts. Only in cases where the maximum-likelihood function thus built is not concave — and no convergence is attained — we resort to ordinary least squares estimation, using some imputation method for the dependent variable (such as the midpoints of the income interval). 


\section{Econometric Results}

\section{A. Main Results}

The wage of Druze men statistically first-order stochastically dominates that of non-Druze Arab men, for both age groups. This is shown in Figure 1.
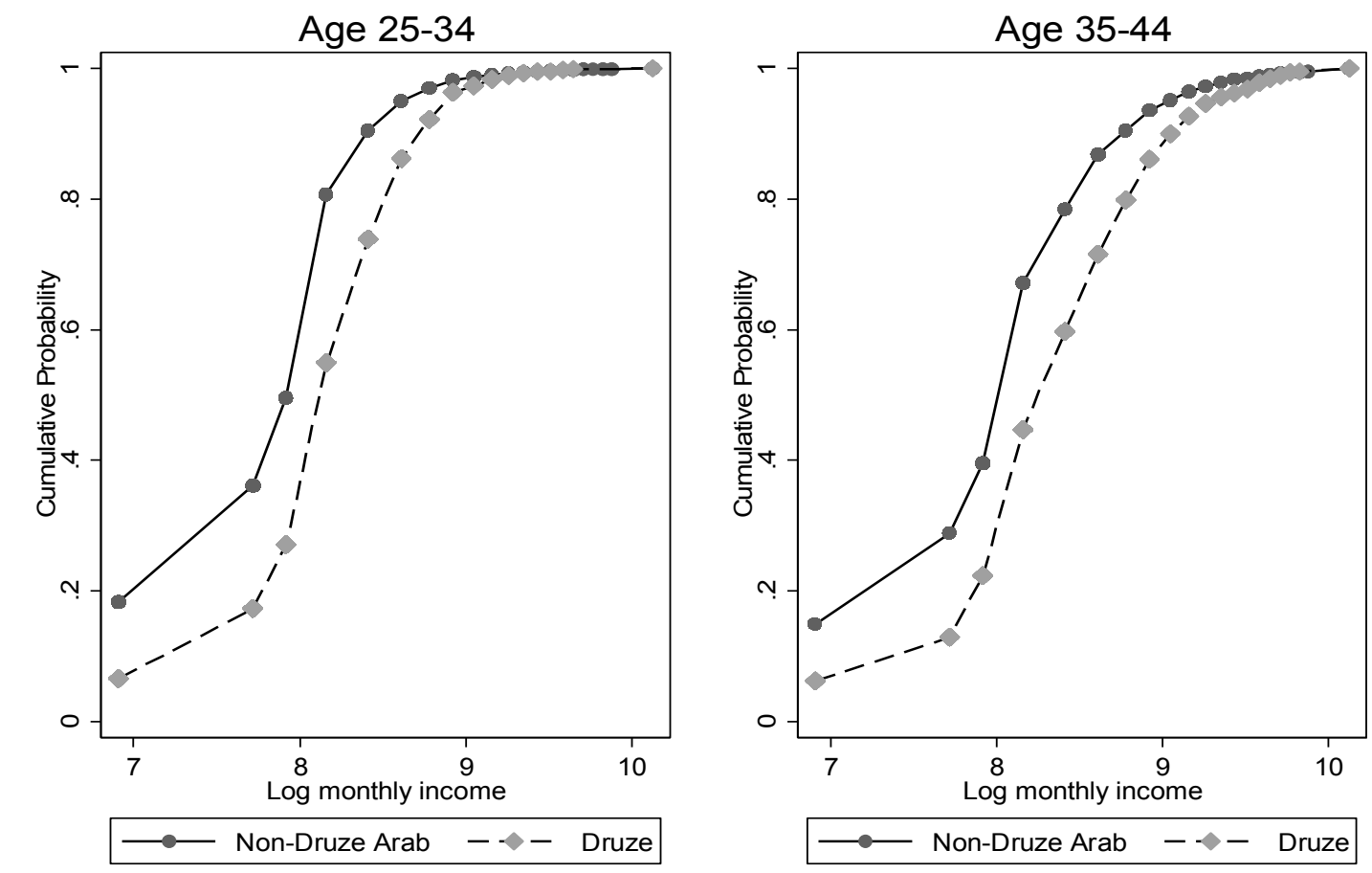

For every income level, the percentage of Druze workers with this or greater income is higher than that of non-Druze Arab workers, for both main age groups (25-34 and 35-44).

Table 2 provides the main estimation results of the effect of conscription on post-conscription earnings. Regression results control for other demographic variables that are not accounted for in the previous graph: variables like marital status, educational level, age group, type of locality, district, sub-district, workplace, occupation, industry, and weekly working hours among other variables. 


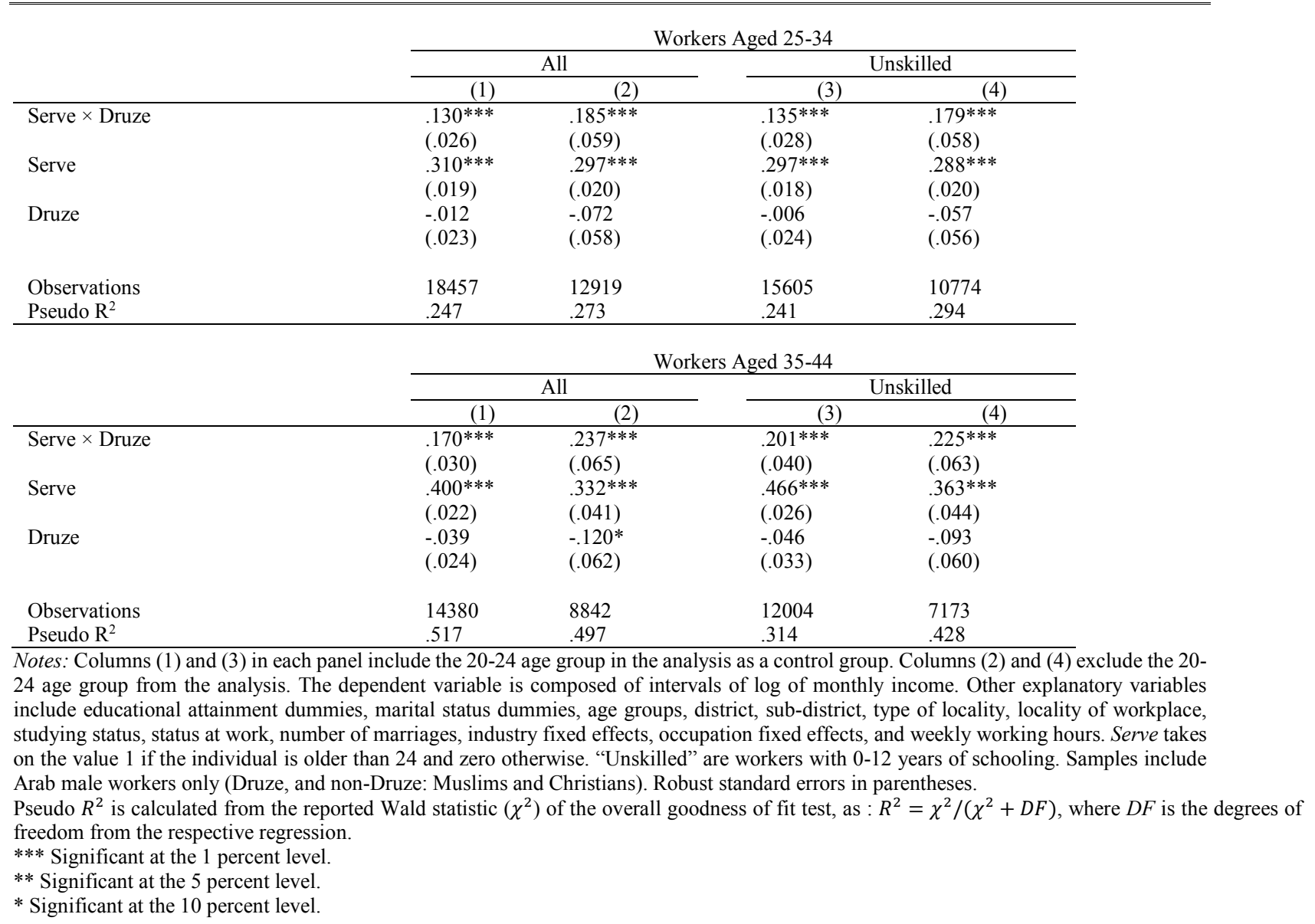

The table presents difference-in-differences (DD) estimates of the effect of military service on future earnings. Columns (1) and (2) pertain to the whole sample within the respective age group; columns (3) and (4) pertain to the unskilled workers within the respective age group (with 0-12 years of schooling).

The upper panel of the table refers to workers aged 25-34 (in the 4-14 years following the completion of military service at the age of 21), and the lower panel to mid-career workers (ages 3544). By default the 20-24 age group is excluded from the analysis (columns 2 and 4 in the above table), so that the comparison is between workers distinctly before military and after military service. However, as a robustness check, we include the 20-24 age group (within which some are still serving, mostly those whose age is up to 22 , and others, $22-24$, are not) with the control group. Results from 
these analyses provide a lower bound of the measured effect—given that some treated workers in this group, namely Druze males, are already working. We report these results in columns (1) and (3).

The coefficient of interest, that of the interaction term Serve $\times$ Druze, measures the effect of military service on future earnings of recent veterans (25-34) and senior veterans (35-44).

The estimated effect of military service for Druze workers from the general sample of the 2534 age group is $18.5 \%$. The estimated effect for the unskilled workers within this group is $17.9 \%$. The effects are economically, and statistically highly significant. If we include the 20-24 age group in the analysis, and treat it like a control group (beside those aged 15-19), we arrive at a lower bound of the estimated effect, which is $13 \%$ and $13.5 \%$ for the whole and unskilled group, respectively. Once again, these effects are both economically highly significant, and statistically significant at all conventional levels.

The lower panel of the table, pertaining to workers aged 35-44, shows that the effects of military service are long-lived, and can even intensify with time. For the general sample, with all schooling levels, the effect is $23.7 \%$, and statistically significant (this is $5 \%$ more than the comparable younger group). Similar effects are found for the unskilled group in this age category. There is no evidence that the unskilled Druze workers benefit more from the military service than the rest of their group. ${ }^{14}$

The military wage premium is interestingly very large (at least $13 \%$ for recent veterans) and increases with time (reaching $17-24 \%$ for senior veterans). Consequently, the service not only provides a stepping stone into the civilian labor market, and an immense advantage at its outset, but also a steeper wage-age profile.

\footnotetext{
${ }^{14}$ The literature provides evidence for a slight advantage for the least skilled workers over others (see Card and Cardoso 2012; Berger and Hirsch 1983).
} 


\section{B. Additional Robustness Checks}

In this section we explore other methodological approaches as well as other institutional particularities to confirm the robustness of the results: in particular the large and significant effect of military service on future earnings.

First, we use propensity score matching to estimate the effects of military service for those who serve (the Druze) as opposed to their non-serving Arab counterparts. The propensity scores (the probability of being in the treatment group) are calculated, using logit model, based on a wide range of demographic and labor related variables. In particular, we control for education levels, marital status (married, divorced, widowed, single), age, locality of workplace, schooling status (never studied, studied in the past, studying presently), marriages (never, once, twice or more, unknown), weekly working hours, status at work (salaried, member of cooperative, one-person business, 2-3 persons business, etc...), industry fixed effects (16 industrial categories), and occupation fixed effects (9 occupational categories).

We match observations from each group (the control and the treatment) with the nearest (one, two, or three) neighbors from the other group, in terms of propensity scores. Increasing the number of nearest matches increases the precision of the estimation (lowers the variance of the estimator) at the expense of a potential increased bias. This is done here as an additional sensitive analysis exercise, given that the single nearest-neighbor estimator is highly significant (precise). ${ }^{15}$

Bootstrap methods are generally used to calculate the standard errors of propensity score matching estimators, because these are not differentiable, and thus the usual derivative-based standard errors cannot be calculated. However, since the propensity scores are estimated as a first step before

\footnotetext{
${ }^{15}$ We also performed many-to-one caliper matching (referred to as "radius matching"), based on the propensity scores; results (not reported) are almost identical to the single-nearest-neighbor propensity score matching estimator reported in the first row of Table 3 .
} 
matching, the bootstrap standard errors, conventionally used in this context, have been shown to be invalid for matching estimators (Abadie and Imbens, 2008). We thus use adjusted robust standard errors as developed by Abadie and Imbens (2009).

Table 3 provides results of the estimated effect of military service on future earnings using propensity score matching approach. The virtue of this method in the current sitting is that it does completely without the pretreatment groups, namely those aged 15-19, or 15-24, and instead focuses on the 25-34 (and 35-44) treated and control groups. Regardless of the pre-treatment group, because these are excluded in the propensity score matching analysis, this method provides a close comparison between the treated group (Druze males after military service, aged 25-34 or 35-44) and the control group (other non-Druze Arabs in the same age categories, but who did not serve in the army).

TABle 3-Robustness Checks: EVIDENCE From PROPENSity SCORE MATCHING

\begin{tabular}{|c|c|c|c|c|}
\hline & \multicolumn{2}{|c|}{ Workers Aged 25-34 } & \multicolumn{2}{|c|}{ Workers Aged 35-44 } \\
\hline & All & Unskilled & All & Unskilled \\
\hline ATE (1 match per observation) & $.169 * * *$ & $.158 * * *$ & $.264 * * *$ & $.189^{* * *}$ \\
\hline $\operatorname{ATE}$ (2 matches per observation) & $\begin{array}{l}.155^{* * * *} \\
(.023)\end{array}$ & $\begin{array}{l}.145^{* * *} \\
(.028)\end{array}$ & $\begin{array}{l}.240 * * * \\
(.030)\end{array}$ & $\begin{array}{l}.240 * * * \\
(.036)\end{array}$ \\
\hline ATE (3 matches per observation) & $\begin{array}{l}.149 * * * \\
(.023)\end{array}$ & $\begin{array}{l}.149^{* * * *} \\
(.024)\end{array}$ & $\begin{array}{l}.222 * * * \\
(.028)\end{array}$ & $\begin{array}{l}.252 * * * \\
(.031)\end{array}$ \\
\hline Observations & 10223 & 8146 & 6268 & 4744 \\
\hline
\end{tabular}

Notes: "ATE" is the Average Treatment Effect in the population. Samples include male Druze workers (treatment) and non-Druze Arab workers (control). The outcome variable is the log of the monthly income (being the midpoint of each income interval). Each subject's propensity score is predicted by a logistic model. Two matches at least are used to estimate the robust standard errors. Matching is performed on all the variables in the wide set of controls, including: educational groups, marital status, age, locality of workplace, weekly working hours, number of marriages, status at work, schooling status, industry, and occupation. Abadie-Imbens adjusted robust standard errors are in parentheses.

*** Significant at the 1 percent level.

The main message form Table 3 is that the effect of military service is indeed large, amounting to $17 \%$ for junior veterans and to $26.4 \%$ for senior veterans. The effects are about $16 \%$ and $19 \%$ for the respective unskilled groups. The results from propensity score matching are in line with our previously reported difference-in-differences results, and attest to the fact that military service in Israel has a large positive effect on the earnings of Druze male workers. 
One can utilize other interesting aspects of the Israeli law, to identify the effect of military service from different angles. As mentioned earlier, the Defense Service law prescribes that (Jewish) women who get married before the conscription age are exempt from serving in the army. Therefore, we can measure the effect of military service by focusing on Jewish women: comparing those who were married before the conscription age (and thus were exempt from service) with those who were single at that age.

This exercise is bound to produce potentially biased estimates of the effect of military service, given that the exemption rule is based on a choice variable (to get married before the age of 19 or not). Notwithstanding, results from this exercise point to a statistically significant effect of $15.4 \%$ and $25 \%$ for the 25-34 and 35-44 age categories of Jewish women; in the least not providing counter evidence as to the large military service premium in the Israeli labor market. ${ }^{16}$ Carrying out the same exercise for Arab women — who do not serve regardless of marital status—yields, as expected, statistically not different from zero effects of -0.06 and 0.03 for the respective age groups.

An additional anomaly in the Israeli law and its practice can be used to identify the effect of military service on future earnings yet from a different angle. As mentioned earlier, Ultra-Orthodox Jews were de facto exempt from military service over the years. The estimation can be done by comparing the change in wages before and after the service age, between secular (serving) Jews and Ultra-Orthodox (non-serving) Jews.

The census does not clearly distinguish between a secular and an Ultra-Orthodox Jew. There is, however, a question about how many years the individual spent studying at a Yeshiva. While this does not guarantee a perfect identification of Ultra-Orthodox Jews, it can be used as the best existing

\footnotetext{
${ }^{16}$ To measure this effect we define the variable 'late marriage' (equivalent to women actually serving in the army) taking the value 1 if married after 19 , and estimate a difference in differences regression of the sort $w a g e=X \beta+$ $\gamma_{1}$ LateMarriage $+\gamma_{2}$ Serve $+\gamma_{3}$ LateMarriage $\times$ Serve. Results are available upon request.
} 
means to proxy for that. Also, in the absence of exogenous effects on the choice into religiosity, the estimated effect is prone to bias. With these qualifications standing, the measured effect of service amounted to a positive and significant $9 \%$. The results here, therefore, should be taken as suggestive at most.

Apart from econometric reasons (identification, small samples, etc...), a smaller effect among the Jewish male community can be economically motivated, and thus reconciled with previous findings, by the fact that minority groups extract higher benefits from the same service, given their lower starting point. This is in line with previous findings in the literature (Berger and Hirsch 1983; Phillips et al. 1992; Angrist 1998; Hisnanick 2003; Hirsch and Mehay 2003; Macias 2003; Nesbit and Reingold 2011, among others).

\section{Falsification Tests}

In this section we focus on the parallel placebo (non-event) case. Namely, since both non-Druze Arab women and Druze women do not serve in the army, the variable Serve (taking the value 1 after the age of 24 and zero otherwise, and thus perfectly indicating a military service for male Druze) does not resemble any real event for these two groups of women. Therefore, if we estimate a difference-indifferences model, identical to that estimated for male workers (of whom the Druze serve and the nonDruze Arabs do not serve), we expect to find no effect of military service.

We therefore estimate equation 1 for Arab females only. In some instances, we resort to ordinary least squares estimation, using the midpoint of the income interval, in cases where the interval regression is not feasible (due to non-concavity of the likelihood function). We also perform similar analysis for this group of female workers using propensity score matching (estimating the average treatment effect for this population, using single-nearest-neighbor propensity score matched estimators). Results are provided in Table 4. 
Table 4-Placebo Analysis: The Case of Non-Serving Arab Females

\begin{tabular}{|c|c|c|c|c|c|c|}
\hline & \multicolumn{3}{|c|}{ Workers Aged 25-34 } & \multicolumn{3}{|c|}{ Workers Aged 35-44 } \\
\hline & $\begin{array}{l}\text { Including } \\
20-24\left(^{\mathrm{a}}\right)\end{array}$ & $\begin{array}{l}\text { Excluding } \\
20-24\left(\left(^{a}\right)\right.\end{array}$ & $\begin{array}{l}\text { Propensity } \\
\text { Scores }\end{array}$ & $\begin{array}{l}\text { Including } \\
20-24\end{array}$ & $\begin{array}{l}\text { Excluding } \\
20-24\end{array}$ & $\begin{array}{l}\text { Propensity } \\
\text { Scores }\end{array}$ \\
\hline Serve $\times$ Druze & $\begin{array}{l}.038 \\
(.042)\end{array}$ & $\begin{array}{l}.076 \\
(.049)\end{array}$ & $\begin{array}{l}.048 \\
(.052)\end{array}$ & $\begin{array}{l}.002 \\
(.066)\end{array}$ & $\begin{array}{l}.126 \\
(.099)\end{array}$ & $\begin{array}{l}.113 \\
(.098)\end{array}$ \\
\hline Serve & $\begin{array}{l}.152 * * * \\
(.038)\end{array}$ & $\begin{array}{l}.102 * * \\
(.041)\end{array}$ & & $\begin{array}{l}356 * * * \\
(.078)\end{array}$ & $\begin{array}{l}.271 * * * \\
(.051)\end{array}$ & \\
\hline Druze & $\begin{array}{l}.025 \\
(.028)\end{array}$ & $\begin{array}{l}-.013 \\
(.038)\end{array}$ & & $\begin{array}{l}.011 \\
(.046)\end{array}$ & $\begin{array}{l}-.096 \\
(.089)\end{array}$ & \\
\hline Observations & 4954 & 3286 & 2618 & 3849 & 2181 & 1486 \\
\hline Pseudo $\mathrm{R}^{2}$ & .367 & .423 & & .564 & .664 & \\
\hline $\begin{array}{l}\text { Notes: see note } \\
\text { It is excluded in } \\
\text { standard errors } \\
\text { a When interval } \\
\text { additional evid } \\
\text { *** Significant }\end{array}$ & $\begin{array}{l}2 \text { and } 3 . \mathrm{T} \\
\mathrm{d} \text { column of } \\
\text { pensity scor } \\
\text { was not fec } \\
\text { nonexisten } \\
\text { level. } * * \mathrm{Si}\end{array}$ & $\begin{array}{l}\text { 20- } 24 \text { age gr } \\
\text { ch panel. Ro } \\
\text { atching esti } \\
\text { le, due to a n } \\
\text { f the effect, } \\
\text { ficant at the }\end{array}$ & $\begin{array}{l}\text { is included i } \\
\text { standard err } \\
\text { rs). } \\
\text { onverging li } \\
\text { was attemp } \\
\text { evel. }\end{array}$ & $\begin{array}{l}\text { t column o } \\
\text { parenthes } \\
\text { values, wh } \\
\text { ad. See tex }\end{array}$ & $\begin{array}{l}\text { h panel as } \\
\text { hd Abadie- } \\
\text { hould per } \\
\text { details. }\end{array}$ & $\begin{array}{l}\text { ontrol group. } \\
\text { ens adjusted }\end{array}$ \\
\hline
\end{tabular}

Apparent from Table 4 is the fact that passing the military age (without actually serving) does not have any effect on future earnings of Druze women beyond that of non-Druze Arab women. The difference-in-differences estimates, the coefficients of Serve $\times$ Druze, are statistically not different from zero. The propensity score matching results, comparing Druze women to non-Druze Arab women after the military service age, also provide estimates of the "non-event effect" that are statistically not different from zero.

The bulk of evidence provided here supports the hypothesis that the difference in differences, and propensity scores, estimates found earlier, comparing the serving Druze men with their non-serving Arab counterparts, are attributable to military service.

\section{Mechanisms and Discussion}

The evidence brought here suggests that military service has an economically significant effect on wages - and more so for minority groups who serve in the army, like Druze Arabs. It is interesting to explore the mechanism behind this positive relationship. Military service can induce behaviors that are responsible for the increased future earnings, such as internal migration, education, beyond any other civilian-relevant military experience and the accumulation of social capital thought networking. 
Two such potential mechanisms are explored in Table 5: first, the probability of relocating or living in the highest-paying city, and second the possibility of attaining more schooling, due to the military service.

We calculate the average income within each locality, and sort these by average income to determine the income percentile to which a locality belongs. Focusing on the localities from which Israeli Arabs come, we define a dummy variable (the top-10\%), which takes on the value 1 if the individual lives in a city that falls among the highest paying cities - those with average income equal or greater to that of the $90^{\text {th }}$ percentile, and zero otherwise. ${ }^{17}$

TABLE 5-MECHANISMS

\begin{tabular}{|c|c|c|c|c|}
\hline & \multicolumn{2}{|c|}{ Living in top $10 \%$ paying locality } & \multicolumn{2}{|c|}{ Having higher education } \\
\hline & (1) & (2) & (3) & (4) \\
\hline & \multicolumn{4}{|c|}{ Workers Aged 25-34 } \\
\hline Serve $\times$ Druze & $\begin{array}{l}.0066 \\
(.0253)\end{array}$ & $\begin{array}{l}.0080 \\
(.0129)\end{array}$ & $\begin{array}{l}.0453 \\
(.0490)\end{array}$ & $\begin{array}{l}.0292 \\
(.0210)\end{array}$ \\
\hline Observations & 13904 & 19909 & 13906 & 19913 \\
\hline \multirow[t]{2}{*}{ Pseudo $\mathrm{R}^{2}$} & .0302 & .0325 & .0496 & .0441 \\
\hline & \multicolumn{4}{|c|}{ Workers Aged 35-44 } \\
\hline Serve $\times$ Druze & $\begin{array}{l}-.0063 \\
(.0275)\end{array}$ & $\begin{array}{l}.0191 \\
(.0145)\end{array}$ & $\begin{array}{l}-.0482 \\
(.0526)\end{array}$ & $\begin{array}{l}-.0308 \\
(.0226)\end{array}$ \\
\hline Observations & 9485 & 15492 & 9485 & 15492 \\
\hline Pseudo $\mathrm{R}^{2}$ & .0342 & .0346 & .0683 & .0586 \\
\hline \multicolumn{5}{|c|}{$\begin{array}{l}\text { Notes: Reported are the marginal effects of the interaction variable Serve } \times \text { Druze based } \\
\text { on the probit regression of } \operatorname{Pr}(y=1)=X \beta+\gamma_{1} \text { Serve }+\gamma_{2} \text { Druze }+\gamma_{3} \text { Serve } \times \text { Druze }+ \\
\varepsilon \text {, where } X \text { includes marital status, age, and education controls in columns }(1) \text { and (2), and } \\
\text { it includes marital status and age controls in columns ( } 3 \text { ) and ( } 4 \text { ). } y \text { stands for "living in a } \\
\text { top } 10 \% \text { paying locality" in columns (1) and (2), and stands for "having higher education, } \\
13+\text {, in columns ( } 3 \text { ) and (4). Columns (1) and ( } 3 \text { ) exclude the } 20-24 \text { age group from the } \\
\text { analysis. Columns ( } 2 \text { ) and (4) include the } 20-24 \text { age group in the analysis as a control group. } \\
\text { Samples include Druze and non-Druze Arab males only. Robust standard errors in } \\
\text { parentheses. }\end{array}$} \\
\hline
\end{tabular}

Columns 1-2 of Table 5 use this dummy of top- $10 \%$ as the dependent variable in a probit regression, with age, marital status, and education as controls, beside the difference in differences variables Serve,Druze, and Serve $\times$ Druze. Reported are the marginal effects of the interaction variable from these probit regressions. This coefficient measures the effect of military service on the probability of living in the top $10 \%$ city. Estimates are reported for workers aged 25-34 and for workers aged $35-44$.

\footnotetext{
${ }^{17}$ Exploring the question with top $1 \%$ and top 5\% yielded similar results.
} 
All estimates, with mixed signs but mostly negative, are neither statistically different from zero, nor economically so. In other words, the probability of geographic relocation to a better paying city or locality is not affected by military service. People who serve in the army and people who do not are equally likely to relocate (or not) to a "rich" city. Internal migration, therefore, appears to play no role in explaining the wage premium associated with military service.

Next, in columns 3 and 4, we examine the schooling channel. It might be the case that those who serve in the army are more likely to acquire higher levels of education or to accumulate more years of schooling, a fact that might account for the wage premium attributed to military service.

Columns 3 and 4 report the marginal effect of military service on the probability of having "higher education" (above high-school), that is, 13 or more years of schooling. The marginal effects are based on a probit model of the probability of gaining 13 or more years of schooling, with controls for age and marital status, in addition to Serve,Druze, and Serve $\times$ Druze. As is apparent from the table, the probability of being highly-educated is not affected by serving in the army. The effects are all estimated to be negative but statistically not different from zero at any conventional significance level.

The body of evidence suggests that neither schooling nor internal migration play an important role in explaining the substantial wage premium associated with military service. The minuscule and statistically insignificant effects shown in the table - for all age-schooling groups — do not support a geographic-based or a schooling-based explanation as to the mechanism behind the military-wage positive relationship. ${ }^{18}$

\footnotetext{
18 This is somehow similar to Card and Cardoso (2012) who reject the location or experience as mechanisms through which the military benefits accrue, although they find a slight positive effect of education as a channel for that effect.
} 
The data at hand do not allow for the exploration of other channels for the large positive effect of military service on civilian wages in Israel. One postulated likely explanation, nevertheless, is networking, which is of a major importance in a very small country like Israel.

The value of networks is the most stressed aspect of social capital-most importantly the interethnic networks (known as "bridging" in sociological literature). First, the social pressure on minority groups to conform to the dominant culture expectations can be alleviated in the military setting as a professional organization providing key opportunities for interethnic and intraethnic networking (Macias 2003), as Druze men in the army serve along their Jewish counterparts. ${ }^{19}$

Furthermore, Annen (2013) showed that social capital can facilitate access to the market and thus substitute for other more costly, formal methods of doing so: this notion pertains to the goods market but can readily be extended to the labor market. The lack of social capital, however, should not be taken as a neutral state: while social is a key for social inclusion of workers in the economy, the lack of social capital can lead to social exclusion - a more acute condition than simple neutrality (Lin et al. 2013 show evidence of this phenomenon for some Asian societies).

Second, and more importantly, it has been found that job candidates benefit immensely from contacts, such that job applicants through referrals were more successful than those applying independently (Obukhova and Lan 2013). Moreover, military service is found to be positively correlated with political engagement (like voting and volunteering), and this relationship is strongest among minority groups (Nesbit and Reingold 2011). Hisnanick (2003) also associated the benefits of military service to social networks "that extend beyond family and local neighborhoods and foster greater independence."

\footnotetext{
${ }^{19}$ At the very early stage of their service (starting in the 1950s) the Druze were concentrated in one unit in the army, used to be known as the "minority regiment" or "battalion 300," but that is not anymore the case (Orgad 2007).
} 
It is not unreasonable to assume that in a small country like Israel, where nearly all large firms and employers are from the Jewish sector, it is highly likely that most workers meet their future employers in the army, and the value of networking is even higher than is generally the case. Therefore, one would not only expect that the Druze (who are a minority serving group) will benefit from their military service, but also that these benefits would be considerable, and manifest in distributional changes (comparing pre-service to post-service employment) in industries in which this community is typically employed - mainly to more connected, politically oriented industries, like business activities and public administration.

Using the current data we see that the civilian industrial affiliation of Druze workers undergoes a major reshuffling after service age, and in different ways than that of the non-Druze Arabs. Druze men, after the service, move from agriculture and construction to manufacturing, real estate, and public administration mostly, industries that which can benefit from the connections formed during the service - and some of which are impossible to join without having served in the army. (It is important to emphasize that this pattern is not observed for Druze females, who do not serve in the army.)

Aggregate changes in the industrial distribution of Druze versus non-Druze workers also lend support to the networking hypothesis. The reallocation rates (the sum of the percentage changes in industrial affiliation) are much higher for Druze workers $(61.8 \%$ and $58.4 \%$ as opposed to the nonDruze $19.4 \%$ and $27.1 \%$ for the $25-34$ group and the $35-44$ group, respectively). Also the maximum shift per a single industry is larger among Druze workers than non-Druze (18.64\% versus 5.09\%, and $15.1 \%$ versus $5.93 \%$, for the respective age groups). The major reallocation experienced by Druze 
workers is also apparent from the high standard deviations of these changes $(6.9 \%$ versus $2 \%$ for the non-Druze Arabs): a sign of higher volatility in the shifts between industries. ${ }^{20}$

It is worth emphasizing that, while some minority groups, namely the Druze, benefit from military service, the benefits are not enough to close the existing wage gap between Israeli Arabs and Jews - the pre-military Jewish-Arab wage gaps are even exacerbated after service. ${ }^{21}$ Similar to Phillips et al. (1992), the limited post-service earnings gain perhaps reflects the effects of discrimination in the civilian labor market.

\section{Conclusion}

Utilizing the institutional setting provided by Israeli laws and regulations, this study measures the effect of military service on subsequent civilian labor market earnings. It finds a large, positive, and significant wage premium for service - such that it more than compensates for the lost labor market experience during service years. In particular, the net effect ranges from $18 \%$ in the $4-14$ years following service, to $23 \%$ in the $15-25$ years following service.

The evidence provided in this study does not support classical explanations for the positive effect of military service on wages; in particular, the educational channel or internal migration are rejected as mechanisms for the transmission of this effect. Descriptive evidence supports the networking (social capital) explanation for the large wage premium of military service found in this study.

\footnotetext{
${ }^{20}$ One additional possible venue through which the wage premium materializes is the command of the Hebrew language. One can postulate that, through their three years of military service beside their fellow Jewish soldiers, the Druze's command of the Hebrew language and their accent improve in ways that warrant premium in the civilian labor market. The data at hand, however, render testing this hypothesis infeasible.

${ }^{21}$ Asali (2010) reports large and unexplained wage gaps between Arabs (who include the Druze) and Jews in Israel.
} 


\section{REFERENCES}

Abadie, Alberto, and Imbens, Guido W. 2008. "On the Failure of the Bootstrap for Matching

Estimators.” Econometrica 76 (6): 1537-1557.

Abadie, Alberto, and Imbens, Guido W. 2009. "Matching on the Estimated Propensity Score.” NBER Working Paper No. 15301.

Angrist, Joshua D. 1990. "Lifetime Earnings and the Vietnam Era Draft Lottery: Evidence from

Social Security Administrative Records.” American Economic Review 80 (3): 313-336.

Angrist, Joshua D. 1998. "Estimating the Labor Market Impact of Voluntary Military Service Using Social Security Data on Military Applicants.” Econometrica 66 (2): 249-288.

Angrist, Joshua, and Krueger, Alan B. 1994. "Why Do World War II Veterans Earn More than Nonveterans?" Journal of Labor Economics 12 (1): 74-97.

Angrist, Joshua D., and Stacey H. Chen. 2011. "Schooling and the Vietnam-Era GI Bill: Evidence from the Draft Lottery." American Economic Journal: Applied Economics 3 (2): 96-118.

Angrist, Joshua D., Stacey H. Chen, and Jae Song. 2011. "Long-Term Consequences of VietnamEra Conscription: New Estimates using Social Security Data.” American Economic Review 101 (3): 334-338.

Angrist, Joshua D., and Jorn-Steffen Pischke. 2008. Mostly Harmless Econometrics. Princeton, NJ: Princeton University Press.

Annen, Kurt. 2013. "Social Capital as a Substitute for Formality: Evidence from Bolivia.” European Journal of Political Economy 31: 82-92. 
Asali, Muhammad. 2010. "Jewish-Arab Wage Gaps: What are the Causes." Defence and Peace Economics 21 (4): 367-380.

Asali, Muhammad. 2013. "The Effect of Immigration on Unskilled Native Workers: Evidence from a Natural Experiment.” Southern Economic Journal 80 (2): 345-365.

Atashe, Zeidan. 1997. Druze \& Jews in Israel-A Shared Destiny? Portland, OR: Sussex Academic Press.

Bauer, Thomas K.; Bender, Stefan; Paloyo, Alfredo R.; and Christoph M. Schmidt. 2012. "Evaluating the Labor-Market Effects of Compulsory Military Service.” European Economic Review 56 (4): 814829.

Berger, Mark C., and Barry T. Hirsch. 1983. "The Civilian Earnings Experience of Vietnam-Era Veterans.” Journal of Human Resources 18 (4): 455-479.

Card, David, and Ana Rute Cardoso. 2012. "Can Compulsory Military Service Raise Civilian Wages? Evidence from the Peacetime Draft in Portugal." American Economic Journal: Applied Economics 4 (4): 57-93.

Cohen, Hillel. 2010. Good Arabs: The Israeli Security Agencies and the Israeli Arabs, 1948-1967. Berkeley, CA: University of California Press.

Cohen, Ra'anan. 2009. Strangers in their Homeland: a Critical Study of Israel's Arab Citizens. Portland, OR: Sussex Academic Press.

Elder, Glen H. 1986. “Military Times and Turning Points in Men's Lives.” Developmental Psychology 22 (2): $233-245$. 
Grenet, Julien; Hart, Robert A.; Roberts, J. Elizabeth. 2011. "Above and Beyond the Call. Long-Term Real Earnings Effects of British Male Military Conscription in the Post-War Years." Labour Economics 18 (2): 194-204.

Hirsch, Barry T., and Stephen L. Mehay. 2003. "Evaluating the Labor Market Performance of Veterans Using a Matched Comparison Group Design.” Journal of Human Resources 38 (3): 673700.

Hisnanick, John J. 2003. "A Great Place to Start: The Role of Military Service on Human Capital Formation." Labour 17 (1): 25-45.

Johnson, Elizabeth. 1960. “Keynes’ Attitude to Compulsory Military Service.” Economic Journal, 70 (277): 160-165.

Knesset, The. 1949. "Defense Service Law." The Book of Laws, 25: 271-278. (http://www.knesset.gov.il/review/data/heb/law/kns1 defense.pdf, accessed 16-01-2014)

Knesset, The. 1986. "Defense Service Law: Consolidated Version." The Book of Laws, Nevo Publishing: Laws Archive (www.nevo.co.il/Law_word/law01/P199 009.doc, last accessed 16-012014)

Lin, Ka; Xu, Yun; Huang, Tianhai; and Zhang, Jiahua. 2013. "Social Exclusion and Its Causes in East Asian Societies: Evidences from SQSQ Survey Data.” Social Indicators Research 112 (3): 641-660.

Macias, Thomas. 2003. "The Changing Structure of Structural Assimilation: White-Collar Mexican Ethnicity and the Significance of Ethnic Identity Professional Organizations." Social Science Quarterly 84 (4): 946-957. 
Nesbit, Rebecca; and Reingold, David A. 2011. "Soldiers to Citizens: The Link between Military Service and Volunteering.” Public Administration Review 71 (1): 67-76.

Nisan, Mordechai. 2010. "The Druze in Israel: Questions of Identity, Citizenship, and Patriotism." Middle East Journal 64(4): 575-596.

Obukhova, Elena, and George Lan. 2013. "Do Job Seekers Benefit from Contacts? A Direct Test with Contemporaneous Searches.” Management Science 59 (10): 2204-2216.

Oi, Walter Y. 1967. "The Economic Cost of the Draft.” American Economic Review 57 (2): 39-62.

Orgad, Liav. 2007. "The Arab Minority in Israel and the Duty of Defense Service." Hamishpat, 11: 381-407. (Hebrew.)

Phillips, Robert L.; Andrisani, Paul J.; Daymont, Thomas N.; Gilroy, Curtis L. 1992. "The Economic Returns to Military Service: Race-Ethnic Differences.” Social Science Quarterly 73 (2): 340-359.

Stewart, Mark B. 1983. "On Least Squares Estimation when the Dependent Variable is Grouped." The Review of Economic Studies 50 (4): 737-753. 